European journal of American studies

Special Issue: Harriet Prescott Spofford: The Home, the Nation, and the Wilderness

\title{
Harriet Prescott Spofford's Development of a Protestant Aesthetic for a Diverse Nation
}

Paula Kot

(2) OpenEdition

Journals

Electronic version

URL: https://journals.openedition.org/ejas/14895

DOI: $10.4000 /$ ejas. 14895

ISSN: 1991-9336

Publisher

European Association for American Studies

Electronic reference

Paula Kot, "Harriet Prescott Spofford's Development of a Protestant Aesthetic for a Diverse Nation", European journal of American studies [Online], 14-3 | 2019, Online since 29 October 2019, connection on 08 July 2021. URL: http://journals.openedition.org/ejas/14895 ; DOI: https://doi.org/10.4000/ejas. 14895

This text was automatically generated on 8 July 2021.

Creative Commons License 


\title{
Harriet Prescott Spofford's Development of a Protestant Aesthetic for a Diverse Nation
}

\author{
Paula Kot
}

1 In "Charlestown," an historical sketch from her 1871 collection New-England Legends, Harriet Prescott Spofford examines the contest between Protestantism and Roman Catholicism that shaped Americans' understanding of democracy as well as Spofford's understanding of her role as an author in an increasingly heterogeneous nation. ${ }^{1}$ The sketch focuses on the 1834 burning of the Ursuline Convent and School of Mount Benedict in Charlestown, Massachusetts, by a Protestant mob, an assault that affords Spofford the opportunity to examine the nation's ability to accommodate difference of all kinds. Born in 1835 and publishing the tales that first brought her to public notice in the 1860s, Spofford came of age as the nation underwent a series of crises that threatened its survival. This turbulent period was marked by territorial expansion, conflict with Native Americans, slavery, sectionalism, the Civil War and its aftermath, and the influx of immigrants, especially Roman Catholic immigrants, who represented to the predominately Protestant population an uncanny mix of foreign and familiar. Significantly, Spofford came of age in New England, where the seeming invasion of Roman Catholic immigrants was met with what Marie Anne Pagliarini calls an "unprecedentedly virulent" form of anti-Catholicism, fueled by the wide consumption of anti-Catholic convent tales and by the inflammatory rhetoric of influential Protestants, including the anti-Catholic sermons delivered by Lyman Beecher in Boston the day before the Charlestown attack (Pagliarini 97). In her sketch, Spofford notes the proximity of the violence against Catholics to the site of the Battle of Bunker Hill to embed it within the republic's larger history and the challenge of accommodating difference within a shared social and political structure. As Sharon M. Harris explains of other nineteenth-century women writers who also wrote "at moments of cultural crisis," Spofford sketches out the history of this important New England city as "a means of contextualizing a nation's actions and building confidence in its survival" (Harris 292). 
2 On its most basic level, the sketch works to promote religious tolerance in Spofford's contemporary audience by exposing the bigotry of antebellum New Englanders. On a deeper level, she suggests that the threat to American pluralism comes not from individual Roman Catholics or Protestants. Spofford detaches the principles traditionally associated with these religious institutions and relocates them in people's mindsets. ${ }^{2}$ Against the backdrop of the nation's territorial and population expansion, Spofford represents the continuing threat to American pluralism as a contest waged within the private spaces of the minds and hearts of Americans. She guides readers through a physical landscape that challenges them to contemplate the engrained bigotry that characterizes their own inner terrain. Her historical tour of Charlestown presents readers with a series of paradoxes associated with democracy that requires them to discard passive thinking and actively reflect on the paradoxical nature of a union that is founded on the notion of "from many, one" (8). ${ }^{3}$ Spofford promotes what has traditionally been seen as Protestant values-the focus on individual judgment and conscience-as what should drive American progress but recognizes that centuries of virulent anti-Catholicism have functioned to create a culture that has come to resemble its vilified Other-becoming in essence a tradition that colonizes minds and displaces individual opinion. She employs the permeability of the physical border of a nation that was expanding as a metaphor for the porousness of the conceptual border between the domestic and foreign, American and Other. In retelling the history of Charlestown, she creates a topsy-turvy realm of shifting and blurring categories that stretches identities and unexamined assumptions and turns readers' anti-Catholic fears against them. The convent becomes an embodiment of the domestic realm-an image of both the home and the republic, as well as of the mind itself. All of these sites are threatened by the actions of a Protestant mob, whose invasion of women's private space taps into Protestant fears of priests' violation of women in the convent and confessional, and whose wanton violence reenacts British redcoats' invasion of Charlestown in an early battle of the American Revolution.

Spofford thus involves her audience in the creation of a new, usable past to unify public opinion and counter the centrifugal tendencies of nineteenth-century America. Yet she does not replace bigoted narratives with other master narratives. Spofford resists developing a narrative that would implicate her in the suppression of views and voices associated with the repressive acts of bigoted Protestant mobs and what was viewed as Roman Catholicism's undemocratic suppression of individual opinion, a suppression accomplished not only through papal control but through the invasion of the private spaces of the mind in the confessional. Instead, Spofford adopts a Protestant aesthetic in order to unify an increasingly heterogeneous nation: one that rejects a reliance upon the authority of the past yet engages readers in the process of deriving meaning from the artifacts of the past. As a writer whose work leads her into the private realm of the reader's mind, Spofford develops a participatory model of creating consensus that replicates the dynamic of democracy in the public sphere. She attempts to recolonize her readers' minds and hearts by creating room for the reader's imagination in her sketch and involving them in the exploration of ambiguity that lies at the core of American identity-an attempt that requires that scholars reassess the critical reputation that Spofford has gained for bigotry and for unthinking support of imperialism. 


\section{Promoting the March of Noble Thought}

4 positions her reader as a "traveler" departing by way of the Eastern Railway and passing through towns "all more or less historic" before arriving at his destination ("Charlestown" 8). Her descriptive tour of the city first takes the reader to the Navy Yard and State Prison, and then moves to "quite another" section of the city, one made famous by the Battle of Bunker Hill. The "suggestions of the scene" lead Spofford to bring back to life for readers the events of the battle, which in turn call up "another morning fifty years later" when the aging veterans who had "helped to lay the cornerstone of the Republic" by attempting to defend the city against the British then laid the "corner-stone" of a monument to celebrate the battle as one of the nation's "first struggles for existence" (8). Working by association, Spofford's story of the British soldiers' burning of Charlestown leads to a reflection on the Protestant mobs' burning of the convent thirty-five years earlier. Spofford recounts the founding of the convent and school in 1820 and its early success, expanding its campus and number of students and sisters despite the antagonism of a town that was "distrustful of Roman Catholic institutions" (10). She explains how the mob attack in 1834 was touched off by the decision of Sister Mary John, or Miss Elizabeth Harrison, the overworked music teacher, to temporarily leave the convent because of poor health-a seeming innocuous event but one that assumed significance because it aligned with the Protestant community's suspicions about convents as they had been developed by the popularity of antiCatholic convent tales. Spofford describes the town Selectmen's visit to the convent and their demands to see Miss Harrison. She details the invasive nature of their fruitless search and their determination to publish a piece in the local newspaper to that effect to quell tensions. Spofford retells the night of the attack, as a working-class mob gathers, using "impertinent language" and demanding to see the "nun that had run away" (12). Spofford describes in detail the near escape of the students and sisters, and the seven-hour long pillaging and wanton destruction of the campus by the mob, and concludes her sketch by detailing the inability of the legislature to "address this assault and make reparation" (14).

In her tour of the city of Charlestown, Spofford retells the history of this city while imaginatively standing atop Bunker Hill and viewing the monument. This literally and conceptually elevated viewpoint offers readers the opportunity to reflect on what she believes is "peculiarly typical of our national [character]": an exemplary devotion to the principle of freedom ("Charlestown" 9). Although Spofford reminds readers that the monument actually marks the site of a Revolutionary War defeat-the inability of local farmers to stop British soldiers from breaching their hastily constructed breastworks-for Spofford, the site memorializes the earnestness of the untrained and poorly equipped American rebels, whose resistance to the "invading" soldiers had the "moral effect in teaching the enemy" of the fledgling nation's unifying principle (9). Spofford describes the farmers' breastworks, a "rail fence stuffed with meadow-hay," as "the first redoubt of freedom the wide world over," a defensive structure that laid "the corner-stone of the Republic" (8-9). Suffused with the "emotion of patriotism" evoked by this site, she asserts that "from Bunker Hill began that march of noble thought and grand action across this continent which is destined to overthrow all tyrannies, both of intellect and of empire, in this hemisphere to-day, to-morrow in the other" (9).

European journal of American studies, 14-3 | 2019 
Spofford imagines the walls and borders of the republic continually expanding outward. She identifies her role as promoting the "march of noble thought" that will overthrow tyrannies of intellect and empire. She understands her own work as intertwined with the "march of ... grand action," the political work of men, in the process of imperialism, but her sense of this role is nuanced, representing both the emotional and patriotic ideal as well as combating its dark and violent incarnation. The benign rhetoric of the American republic's march is set side-by-side with the brutal march of the invading British soldiers and eventually leads to the Protestant mob's march on the Ursuline convent. Her rhetoric suggests that she sees women and men uniting to fulfill America's destiny, but it also suggests that this destiny can only be achieved through the protection of human rights and freedom of thought for all within its borders. ${ }^{4}$

6 The Bunker Hill breastworks, as representative of the expanding borders of the nation and its values, typify the continuing challenge to the republic's preservation and expansion. In reminding readers of its construction of sod and hay, Spofford emphasizes the permeability of this defensive boundary, a quality reinforced as she transforms the breastworks into the infinitely expanding borders of the republic. The expansion of the nation and its population-incorporating what Spofford calls elsewhere the "new ways, new faces, new customs" of immigrants into the nationweakens and dissolves the boundary between domestic and foreign territory, American and Other, freedom and tyranny (The Servant 26). ${ }^{5}$ As Amy Kaplan explains of the architectural metaphors used by nineteenth-century women writers who, like Spofford, viewed women's role as having global influence, "the construction of an edifice ordinarily entails walling off the inside from the outside," but the "distinction between inside and outside" is "obliterated by the expansion of the home/nation ... to encompass the globe" (31). Spofford thus explores the paradox involved in nation building and the identity formation of Americans that Kaplan has identified in the works of other nineteenth-century American writers: the expansion of the nation and its population, the teleological fulfillment of its destiny, seemingly challenged national stability by incorporating foreign customs and views.

7 For Spofford's contemporaries, one of the most serious challenges to the teleological view of the boundless expansion of the American republic and its values was the presence of Roman Catholic immigrants-what Susan Griffin calls the "familiar yet foreign presences making themselves at home in ... America" (Anti-Catholicism 7). Griffin explains that the United States, like Britain, "had long traditions of anti-Catholicism," but in the U.S., "the heavy Irish immigration ... following the 1845 failure of the potato crop" magnified Protestants' fears (3). Griffin describes how "the Roman Catholic population of the United Stated burgeoned, so much so that by 1850 Catholics comprised the single largest Christian denomination in the country" (3). Spofford's sketch uncovers the nation's correspondingly paradoxical response to this seeming Roman Catholic invasion: Protestants sought to preserve the union that had been founded on the principle of freedom by violently suppressing the views that they believed threatened unity. The sketch's focus on the backlash against Catholics demonstrates that the threat of tyranny lies not only outside the nation's borders, but within, and Spofford writes to promote the "march of noble thought" by, in effect, "teaching"-as the revolutionary rebels had taught British soldiers-and assimilating 
through her sketch those readers whose beliefs or actions threaten America's unifying purpose.

Spofford guides her readers to Bunker Hill to renew their commitment to freedomjust as that commitment had been renewed when the Bunker Hill monument had been erected fifty years after the battle. She recognizes that this site provides the proper perspective for reflecting on an historical event associated with a form of tyranny that had challenged America throughout its history. Spofford redirects her reader's gaze to the ruins of the Ursuline Convent and School of Mount Benedict. She explains how an "inherited dread of papacy and its influence" and "swarms of suspicions" concerning the "abominated" Roman Catholic Church led to the destruction of the convent by a Protestant mob in 1834 (10). Spofford most likely focuses her sketch on this instance of bigotry because of its far-reaching influence. Marie Anne Pagliarini explains that "within a week of the Ursuline burning, two new anti-Catholic newspapers began publication," one in Philadelphia and one in New York (Pagliarini 119), and a wave of bigotry followed, including rioting and murder, the destruction of Roman Catholic homes and churches, the drafting of anti-Catholic legislation to inspect convents, and the rise to power of the nativist, anti-Catholic political party, the Know-Nothings (97). ${ }^{6}$ In her historical sketch, then, Spofford links two originary moments: the battle that represents the first steps of the fledgling republic and, as Pagliarini describes, a riot that touched off "the anti-Catholic sentiment that swept over antebellum America" (97). While commentators in the 1830s had noted the physical proximity of these two sites to justify the convent's destruction as an effort to protect American freedom, ${ }^{7}$ Spofford notes their proximity to denounce the attack as nothing less than an "outrage on human rights and freedom of thought," which, she adds, "it is to be hoped, neither this country nor this age shall behold again" (Spofford 9). Spofford focuses her sketch on uncovering the "steadily smoldering fires of hate" passed down and sustained through anti-Catholic literature that characterizes the history of New England.

\section{The Colonizing Structures of Anti-Catholicism}

Spofford's initial architectural metaphor, imaging the republic as an expanding edifice, invites her readers to reflect on nation building, specifically on the entrenched ideological framework of anti-Catholicism that upholds and shapes the American imagination and its institutions. She develops this metaphor in her tour of Charlestown, a "city of walls and towers," by focusing on a series of seemingly impenetrable defensive structures associated with the powerful "machines"-the military, civic, and religious institutions-responsible for the maintenance of order in the nation and for shaping public opinion (8): The rebels' breastworks at Bunker Hill had been transformed fifty years later into an enclosure and gray shaft rising from the summit; the "massive granite wall" that encloses the Navy Yard; the State Prison, "entrenched behind its perpendicular fortifications and rows of spikes"; the "broken walls and chimneys" of the Ursuline Convent; and rising "far above them all," as the streets of Charlestown "[lift] in tier over tier," the "lofty spire of the hill-top church" (8-9). Save for the convent's broken walls, Spofford describes at length the solidity and permanence of the built environment of Charlestown in order to suggest the resilience of the "cultural structures-colonizing structures-[that] take shape inside as well as outside minds and bodies." ${ }^{8}$ She notes the upward trajectory of the city, with the 
Protestant church spire raised far above the other structures, in order to illustrate how these powerful ideological machines both support and are led by the teleological belief that linked the progress and perfection of the nation and world, "the global march of civilization," to the "progressive religious development" of Protestantism away from Roman Catholicism (Griffin Anti 5). The relationship between the town's many fortified walls and the convent's broken walls suggests not only the failure of American institutions to protect freedom during the 1834 attack but that religious bigotry against Roman Catholicism is built into the teleological narrative that informs these institutions and American life.

In "Charlestown," Spofford attempts to rehabilitate the hearts and minds of Protestant Americans, to free them from the tyranny of anti-Catholic bigotry, and thus facilitate the forward movement of the "wheels of progress." She does so by exposing her readers to the intermeshed nature of domestic and foreign, freedom and tyranny, liberty and captivity. In the opening paragraphs of the sketch, Spofford directs her reader's gaze to the State Prison, one of several heavily fortified structures of the town, and asks him to reflect on the seeming "inconsistenc[y] between theory and practice" in Massachusetts-the birthplace of American freedom-that the State Prison is "almost the only place within her borders, where a liberty-cap is displayed" (8). Spofford quickly adds that this is "not so glaring an inconsistency ... as it at first sight appears, since the imprisonment of criminals means the freedom of all the rest of society" (8). As she does throughout the sketch, Spofford guides her reader past first impressions and unexamined assumptions and asks him to reflect on the paradoxical nature of American democracy, one that contains within its expanding borders heterogeneous views. Spofford focuses on the prison's "perpendicular fortifications and rows of spikes" as a representation of the seemingly impenetrable nature of inherited ideological constructs that imprison the Protestant American imagination. Spofford also uses this particular site to point to nativist representations of convents as “"priests' prisons for women" in anti-Catholic literature9-which were, as Marie Anne Pagliarini writes, "a crucial factor in major incidents of convent violence" and certainly one that motivated the 1834 attack (Pagliarini 117). Furthermore, Spofford draws upon the nativist perception of Catholic dogma as itself imprisoning. ${ }^{10}$ Spofford calls this site "another lion" of Charlestown, or another of the powerful machines used to maintain order within the nation, in order to emphasize the failure of institutions to protect civil liberties ("Charlestown" 8). The sketch describes not only the institutionally approved destruction of the convent-the participation of Selectmen in the attack-but concludes with Spofford's indignation that the men tried for this attack were acquitted and that the state in effect "has virtually repeated the outrage year by year" by refusing to acknowledge and make reparations for the convent's losses (14). In other words, because of the institutionalization of bigotry against Catholics, those who betrayed America's values were never placed within prison walls, but remain outside. Like her initial depiction of the porousness of the republic's boundaries, Spofford problematizes the relation between internal and external. But Spofford asks her reader to note both the prison walls and the "number of officials necessary to carry on its operations and maintain order" within the prison and by extension, within the nation (8). Spofford projects herself within the walls-caught within even as she attempts to dismantle the ideological structures of anti-Catholicism. 
11 After all, Spofford was addressing an audience that was-like the 1834 mob-still "constantly fearful of Catholic supremacy" (10); moreover, these fears had been exaggerated by nativists throughout the antebellum period in order to unify an increasingly fragmented nation, to mark off and police the borders between American and Other, domestic and foreign. ${ }^{11}$ The influx of Roman Catholics into the Northeast had brought to power in Massachusetts-Spofford's home state-the Know-Nothing party in the 1854 and 1855 elections (Griffin Anti 91). Nativists argued that the stability and prosperity of the nation depended on unanimity of thought and action, a unanimity that they asserted was threatened by Catholic immigrants (Griffin 4). In a nation increasingly fractured by immigration, Protestants could agree that the "common antagonist" was Roman Catholicism, as Henry Augustus Boardman expressed it in an 1840s lecture (17). Boardman's anti-Catholic rhetoric urged Protestants to fortify themselves; he warned, "It ill becomes us, with the records of history open before us, to dismantle our fortresses, and disband the garrisons, and throw open the gates, while such an enemy as Popery is hovering around" (10). As Susan Griffin explains, "nativism offered 'national homogeneity' to a country threatened by sectionalism and facing growing religious diversity and disaffection" (Griffin 94). Spofford, then, faced a paradoxical challenge in writing "Charlestown": in order to create consensus, she needed to dismantle the very fears that had been used by nativists to unify the nation. Furthermore, she needed to re-educate what she calls the "bigoted and narrow-minded of the untaught population" without engaging in a form of intellectual tyranny herself, without denying the right of individual opinion (“Charlestown" 12).

12 Yet Spofford's attempt to defend the freedom of conscience of Roman Catholics-and thus, by extension, of America itself-is complicated by the fact that she herself was not immune to the nativist rhetoric that fanned the flames of bigotry throughout the antebellum period. Spofford demonstrates this influence in her sketch when she associates the Catholic Church with a form of intellectual tyranny at odds with American values, giving voice to the pervasive fear that "Catholic obedience to the Papacy was incompatible with either independent citizenship or loyal subjecthood" (Griffin 4). Although Spofford focuses a great deal of the sketch on ridiculing the antiCatholic beliefs that flared into mob violence against individual Catholics in Charlestown, she legitimizes fears of Catholic "supremacy" that result from what she describes as a "largeness of view," the ostensibly enlightened perspective that "as a Church of authority," the Catholic Church "[denies] the right of individual opinion" (Spofford 10). Furthermore, Spofford's motivation for writing this sketch and educating readers about the dangers of bigotry indicates that she had absorbed nativism's argument about the vital importance of unity to the preservation of the union. In Paddy and the Republic, Dale T. Knobel explains that "Mid-century nativists extracted their certain kind of nationalism from a highly selective (and interpretive) reading of the republic's founding fathers," focusing specifically on the writings of Jefferson and Hamilton (Knobel 144). He writes,

Jefferson had written that effective civil government 'must be conducted by common consent' growing out of popular subscription to common 'principles,' and Hamilton ... observed that 'the safety of a republic depends essentially on the habits of a common national sentiment; on a uniformity of principles and habits,' ... [and] recommended that 'to render the people of this country as homogeneous as possible, must lead ... to the permanency of their union and prosperity. (Knobel 144) 
13 Spofford exposes her absorption of nativism's insistence on homogeneity in another sketch from her collection of New-England Legends, entitled "Dover," when she writes of the "divided ... opinion" that obstructed early settlers from "establish[ing] a government of mutual concessions" ("Dover" 29). What was "necessary" during this early time of crisis was what she calls "perfect unanimity of heart and mind" (29). For Spofford, unity of heart and mind had been and continued to be the key to preservation of the union. Nativists used the notion of homogeneity to justify their attack on Roman Catholicism and Roman Catholics as foreign to American institutions; Spofford endorses this notion to challenge anti-Catholic bigotry as foreign to American principles.

\section{Dismantling Anti-Catholicism}

Spofford organizes "Charlestown" and the other sketches in the collection as a series of sights viewed from a train "car window," positioning her reader as a traveler inside the car; this structural device embodies the paradoxical nature of American expansion ("Charlestown" 8). On the one hand, Spofford's imagery draws on the commonplace association of trains with America's westward movement and thus links her reader's experience to the teleological narrative that equated progress with the "westward march of empire" (Kaplan 18). She develops this metaphor further in her description of "the wheels of progress," the spread of "noble thought," that must accompany territorial expansion ("Charlestown" 10). On the other hand, the succession of seemingly unrelated views that "open on" the traveler as he journeys through Charlestown-the spire of the hill-top church, the Navy Yard, State Prison, Bunker Hill Monument, and ruins of the Ursuline convent-re-enacts the discontinuity of American experience brought about by the incorporation of new territory and diverse populations (8). While other nineteenth-century writers such as Nathaniel Hawthorne used train travel to evoke the rapid changes associated with modernity, Spofford's sketches present the unsettling perspective created by this mode of transportation as a constant feature of the American landscape. She collapses the past into the present, providing an uncanny counterweight to the teleological narrative, by focusing her sketch on the continuing conflicts created by the different ways, faces, and customs associated with the heterogeneous groups who represent America's past and present.

In this way, Spofford acts as a guide not just to what her reader/traveler should see in visiting Charlestown, but how he should read, or re-read these sites. Spofford's interest in retelling this New England "legend" is on how stories serve as carriers for colonizing ideological structures that-as implied in the sturdiness of the town's built environment-seem permanent. She makes visible residents' inflamed imaginations, the intertextual nature of the attack. Her relation of the events leading up to the destruction of the convent focuses on the familiar plots and characters of anti-Catholic literature that had been promoted by Protestant leaders, especially the convent tale, that, like Maria Monk's bestselling Awful Disclosures of the Hotel Dieu Nunnery (1836), portrays the convent as the site of the sadistic torture of captive women (Pagliarini 112). Spofford describes the "swarms of suspicions" about Roman Catholicism-viewed as "little less than a branch of the Inquisition"-and carried by "such legends as that old one of the unfaithful nun, sealed up alive in a wall"-that motivated the mob to destroy the convent ("Charlestown" 10). She explains that this "old" tale as well as the 
"wood-cuts of 'Fox's Book of Martyrs"' [sic] caused citizens to misread the Ursuline convent, viewing "the quiet building on the hill not as a place of innocent merriment and girlish study, but" "as a den of wickedness and filth," the site "of severe penance, of horrible punishment, of underground cells and passages through which all the mighty power of the Church walked abroad to crush any refractory spirit into death or submission" $(10,12,10)$. Spofford quickly summarizes the thematic strand of convent tales-illicit sexuality, torture, captivity, and the victimization of women-because her own readers would have been as familiar with these tropes as the 1834 Protestant mob. She calls attention to the role of Foxe's sixteenth-century Book of Martyrs in inciting violence to suggest that the Protestant church has become, like its vilified Other, a church of authority, oppressed by inherited and unexamined ideas. She subtly suggests that the centuries-old fear of Catholic tyranny has driven Protestants to do the same. The physical structures of the town make visible the bigoted ideological structures of the mob's and her readers' minds.

Spofford's treatment of the events that set off the Ursuline convent attack sheds light on the role of print in shaping values and behavior and developing consensus and thus reveals the self-reflexive nature of her sketch. In Spofford's sketch the first flare up of violence, the beating of the convent gardener, occurs when the town reads in the "neighboring newspapers" a single paragraph devoted to the rumors circulating about the disappearance of a woman, Miss Elizabeth Harrison (or Sister Mary John), from the convent, identified by the newspapers as "The Mysterious Lady" (12). Spofford explains that citizens' "unfortunate feelings and fancies" about Catholics "glowed more and more hotly, [until] it needed but a single spark to kindle the flame of intolerance into open action among this population, watchful, and ready to give the worst possible construction to every simple circumstance" (10). The "spark" that kindled the violence was the brief disappearance of Miss Harrison, who, overworked and exhausted from her duties as a music teacher at the school, slipped away from the convent but soon returned and begged to be allowed to remain (11). When "magnified and exaggerated" by imaginations inflamed by convent tales and wood-cuts of martyrs, the townspeople interpreted news of her disappearance as evidence that she had been murdered or was being held captive and abused within the convent (12). Spofford explains that the appearance of this story in print represents the "visible and audible expression of what appears to have been in the minds of nearly all" (12) and led to united action, in this case, initiating the mob's "march" on the convent. Spofford also suggests that print makes manifest the private, interior space that had been colonized by anti-Catholic literature, an interior space that Spofford attempts to recolonize through her sketches.

\section{Creating Room for the Reader's Imagination}

The succession of scenes the reader travels through in Spofford's sketch is intended to open in her reader's imagination an expanded conception of what it means to be an American. If Catholics were constructed as the "common antagonist," as Protestant leaders such as Boardman argued, then Spofford writes to enable readers to "throw open" their imaginative "gates," to dissolve entrenched boundaries. At the same time, Spofford imagines her text as open to readers, as creating a realm in which the mutual engagement of text and reader can work to overcome divided opinion and create a new consensus and more stable nation. As writer and guide, she takes as her model 
Shakespeare and Emerson, who, she writes in her 1860 story "Desert Sands," leave "room for [the reader's] imagination" or require readers to "link" ideas "with chains of their own logic" ("Desert Sands" 189). Viewing the relationship between text and reader as a contemporary reader-oriented theorist would, Spofford imagines her sketch as a meeting place and participatory realm that promotes and mirrors the exchange of ideas in the public sphere. She presents her readers with the seemingly disparate legends of Charlestown's past and challenges them to discover connections and create the significance of this past.

The first invasion of the convent occurs after Miss Harrison's return, when five Selectmen and other citizens were guided through the convent, "assisted by The Mysterious Lady, Miss Harrison, herself" ("Charlestown" 12). Spofford clearly suggests the sexually invasive nature of this search of the convent. Ostensibly searching for other captive women, the men use the opportunity to probe and pry into the secret recesses of the convent, "searching every closet, opening every drawer," though Spofford notes that these spaces are not large enough to conceal a captive (12). Satisfied, the men leave, intending to prepare a proclamation to that effect for the morning papers, but that night, a mob forms, demanding to "see the nun that had run away" (12). They assume she is held captive and want to search the convent to release her. Spofford describes how the mob poured into the convent, waving clubs, and purportedly searching for captive women:

Before the last of the children had left the building the varlets had poured in .... In a moment afterward the house was filled with the mob, shouting, yelling, and blaspheming .... They ransacked every room, rifled every trunk, broke open every drawer, stole watches, thrust the costly jewelry of the Spanish children into their pockets, split up the piano-fortes, shattered the splendid harps, and even made way with the altar ornaments .... Having satisfied their curiosity and greed, they piled up the furniture, curtains, books, pictures, in the centre of the several rooms, and deliberately set fire to every heap, threw in the altar vestments, the Bible and the cross, and, the act of virtue consummated, left the building in flames. (13)

Spofford challenges nativist attempts to police the border between the domestic and foreign by depicting the Protestant mob attack as an invasion-the term used by Protestants to express anxiety toward the influx of Roman Catholic immigrants. ${ }^{12}$ Spofford's retelling of Charlestown's history asks readers to link the eighteenthcentury invasion of the British soldiers at Bunker Hill and the mob's invasion of the convent half a century later with contemporary Protestant anxiety about the Catholic invasion of America. She creates an unstable realm of shifting and blurring categories that turns inside out identities and assumptions, and effaces difference, until the male, Protestant mob manifests the terrifying qualities associated with redcoats and Roman Catholics.

Spofford's description of the assault does more than dissolve difference and embed this event within the contest between freedom and tyranny that frames the republic's history; by emphasizing the sexually invasive nature of this attack, she exploits the multi-layered nature of her audience's associations with the private and domestic. She portrays the convent as the embodiment of the domestic sphere, the domestic realm or republic, and the mind itself, all of which are under attack by the male, Protestant mob. Spofford's description of the Ursuline convent as a "quiet building" and "place of innocent merriment" establishes that the Roman Catholic nuns and their convent/ home are associated with the domestic sphere. The Lady Superior, described as 
"thoroughly educated, dignified in her person, and elegant in her manners, pure in her morals, of generous and magnanimous feelings, and of high religious principles," embodies the domestic ideal (12). Spofford also clarifies that the sisters perform women's work-indeed participate in nation building-by domesticating and assimilating the girls who are drawn there "from all parts of the country" and the hemisphere, including "pupils from New England, the West Indies, Southern States and British provinces" (9-10). Yet these girls and women, like the revolutionary farmers at Bunker Hill, become victims to a foreign aggressor. The "group of men" disrupts and defiles this sphere by probing into and invading women's private space-linking the mob's actions to the pervasive fear of priests' violation of the female body in the convent and the female mind in the confessional. ${ }^{13}$ Spofford thus turns readers' antiCatholic fears against them until the assault on the convent comes to embody an assault on the privacy of the mind, the realm of "freedom of thought." In this attack, then, Protestants had committed the same error that they accused Roman Catholicism of: the invasion of the private spaces of the mind, the undemocratic suppression of individual opinion that they believed occurred through papal control and the confessional.

21 The Protestant mob's perception of the threat posed by the convent is revealing; they view it not as a sanctuary from the power struggle between Protestantism and Roman Catholicism, but as an engine for that conflict-as an outpost of the foreign enemy intended to expand its influence into the domestic realm or nation. ${ }^{14}$ As Boardman's lecture makes clear, Protestants feared Roman Catholicism's contaminating expansion, what he calls the "tide of emigration" (Boardman 45). The Protestant mob fears that the convent has been erected for "proselyting purposes" ("Charlestown" 10)converting Protestant American children into Roman Catholic foreigners. First, Spofford debunks the mobs' fears. She explains that these fears were "oblivious of the truth" that "not a single pupil, in all the number educated in the convent, had ever become a nun, nor had one been converted to Catholicism" (10). But Spofford's focus on the mob's fears as well as her detailed description of the actual attack on the convent highlight the precarious role she herself plays as guide in this sketch and the dangers facing the artist who seeks to control and exploit the print medium. She projects onto the mob's reading of the convent the anxiety-ridden role she herself plays-a participant in the process of imperialism, one who colonizes the private, interior realm of the hearts and minds of the "untaught." Tyranny does indeed exist within the nation's borders, and Spofford writes to facilitate American progress without implicating herself in the vices associated with Protestantism and Roman Catholicism.

\section{Reassessing Spofford}

An all-male mob that physically threatens women and searches and defiles their private space, a working-class mob whose violence is incited not only by bigotry but class prejudice against wealthy students, whose "costly jewelry" they steal-in Spofford's retelling of the assault on the Ursuline convent and School of Mount Benedict, the attack on Roman Catholicism comes to represent an attack on difference. As Elizabeth Fenton has found in the writings of other nineteenth-century authors, Spofford uses Catholicism in this sketch as a site for "testing the limits of democracy's capacity to accommodate difference" of all kinds (Fenton 4). On one level, then, 
Spofford writes to expose and dismantle the anti-Catholicism imprisoning the Protestant American imagination. The paradoxical rhetoric that Spofford uses to describe the assault, though, reveals that her concern runs much deeper and has personal significance for her as a writer who seeks to ensure freedom of thought even as she attempts to change entrenched thinking. On a deeper level, she believes that the survival of the nation requires a new perspective in her readers. In exploring the causes of the mob assault on the Ursuline convent, she reveals that from Foxe's sixteenth-century Book of Martyrs to Lyman Beecher's sermons, Protestant leaders have created a dogma that functions to strip individuals of independent judgment as effectively as they argued papal decree or the confessional had. Spofford negotiates this tension between freedom and tyranny by engaging her readers in the development of a national aesthetic. She creates room for the reader's imagination in her sketchexpanding frontiers that allow readers to participate in broadening the definition of the domestic-while reining in and aligning the views that threaten unity.

The cultural politics of Spofford that emerges from this historical sketch differs greatly from the reputation she has gained from her most anthologized tale, "Circumstance" (1860). Judith Fetterley's examination of this story led her to conclude that Spofford was incapable of freeing herself from "racist thinking," unlike other women writers from this period who were able to make "a sincere and serious effort to combat racism in themselves and in their world" (Fetterley 267). Carol Holly's reading of "Circumstance" led her to denounce Spofford for justifying the "American imperialistic ambitions" that led to genocide against Native Americans (Holly 163). As do other sketches from Spofford's 1871 collection New-England Legends, an unexplored part of her oeuvre, "Charlestown" reveals that Spofford was more than just a "complicit carrier" of imperialist ideology. Rather, she was a self-reflecting "cultural theorist" who sought to expose and reshape the entrenched ideological framework that supported bigotry in its many forms. ${ }^{15}$ "Charlestown" demonstrates that Spofford did indeed see herself as a participant in the expansion of the values associated with the American republic but recognized the complex nature of this role. Her understanding of the role she plays in the process of imperialism as a woman writer, as well as her sincere efforts to combat bigotry in herself and in her world, require us to reassess her place within the ranks of nineteenth-century American women writers.

\section{BIBLIOGRAPHY}

Boardman, Henry Augustus. Anti-Catholicism in America, 1841-1851: Three Sermons. Ed. Gerald N. Grob. New York: Arno Press, 1977.

Fenton, Elizabeth. Religious Liberties. Anti-Catholicism and Liberal Democracy in Nineteenth-Century U.S. Literature and Culture. Oxford: Oxford UP, 2011.

Fetterley, Judith. Introduction. Provisions: A Reader from $19^{\text {th }}$-Century American Women. Bloomington: Indiana UP, 1985. 1-40. 
Franchot, Jenny. Roads to Rome: The Antebellum Protestant Encounter with Catholicism. Berkeley: U of California P, 1994.

Griffin, Susan. Anti-Catholicism and Nineteenth-Century Fiction. Cambridge and New York: Cambridge UP, 2004.

---. "Women, Anti-Catholicism, and Narrative in Nineteenth-Century America." The Cambridge Companion to Nineteenth-Century American Women's Writing. Eds. Dale M. Bauer and Philip Gould. Cambridge and New York: Cambridge UP, 2001. 157-175.

Harris, Sharon M. “'Across the Gulf': Working in the 'Post-Recovery' Era.” Legacy 26.2 (2009): 284-98.

Holly, Carol. "Grand and Sweet Methodist Hymns: Spiritual Transformation and Imperialistic Vision in Harriet Prescott's “Circumstance.” Legacy 18.2 (2001): 153-166.

Kaplan, Amy. The Anarchy of Empire in the Making of U.S. Culture. Cambridge: Harvard UP, 2002.

Knobel, Dale T. Paddy and the Republic. Middletown, CT: Wesleyan UP, 1986.

Pagliarini, Marie Anne. "The Pure American Woman and the Wicked Catholic Priest: An Analysis of Anti-Catholic Literature.” Religion and American Culture 9.1 (Winter 1999): 97-128.

Pfister, Joel. "Hawthorne as Cultural Theorist." The Cambridge Companion to Nathaniel Hawthorne. Ed. Richard H. Millington. Cambridge: Cambridge UP, 2004. 35-59.

Spofford, Harriet Prescott. "Charlestown." New-England Legends; with illustrations. Boston: James R. Osgood and Co., 1871. 8-14.

---. "Circumstance." The Amber Gods and Other Stories. Ed. Alfred Bendixen. New Brunswick [N.J.]: Rutgers UP, 1989. 84-96.

---. "Desert Sands." The Amber Gods and Other Stories. Boston: Ticknor and Fields, 1863. 173-217.

---. "Dover." New-England Legends; with illustrations. Boston: James R. Osgood and Co., 1871. 29-35.

---. “Her Story.” The Amber Gods and Other Stories. Ed. Alfred Bendixen. Rutgers UP, 1989. 148-166.

---. "The Amber Gods." The Amber Gods and Other Stories. Ed. Alfred Bendixen. New Brunswick

[N.J.]: Rutgers UP, 1989. 37-83

---. The Servant Girl Question. Boston: Houghton, Mifflin, and Co., 1881.

Sweet, Nancy F. “A Woman with a Cross: The Transgressive, Transnational Nun in Anti-Catholic Fiction." Transnational Gothic: Literary and Social Exchanges in the Long Nineteenth Century. Eds. Monika Elbert and Bridget M. Marshall. London: Routledge, 2013. 97-112.

\section{NOTES}

1. My reading of Spofford's exploration of the contest between Protestantism and Roman Catholicism is indebted to Elizabeth Fenton's Religious Liberties: Anti-Catholicism and Liberal Democracy in Nineteenth-Century U.S. Literature and Culture. Fenton's argument differs from that of Jenny Franchot, who views Catholicism as a "set of beliefs and practices" and anti-Catholicism as "the vehicle through which Anglo-Protestants produced a unified 'Protestant' identity." Instead, Fenton traces anti-Catholicism back to the founding of the nation and views it as "a set of 'imaginative contours and political functions' circulating in U.S. culture" (4). Fenton explains that "the concept of individual freedom ... hinged on an anti-Catholic discourse that presented Protestantism as the guarantor of religious liberty and respect for all kinds of difference- 
political, sexual, and racial as well as religious-in a plural nation" (6). My argument builds on the work of Fenton, Franchot, Susan Griffin, and Marie Anne Pagliarini, all of whom have contributed significantly to the study of Catholicism in the United States, yet none of whom have examined the significance of Roman Catholicism in the writings of Spofford.

2. The confrontation between Protestantism and Roman Catholicism is replayed in tales from this period. See for example Vaughan Rose's antipathy toward the amber beads in Spofford's 1860 "The Amber Gods" and the threat associated with the other woman's convent education and familiarity with the sermons of the "Italian father[s] of the Church" in her 1872 "Her Story" (155). The amber beads, formerly rosary beads, leave the emphatically Protestant Vaughan Rose feeling as if he is "bound ... in a thrall" (65). The convent education and discussion of Catholicism enable the other woman of "Her Story" to "rivet the chains" that entrap Sydney. Catholicism is associated with the loss of independent judgment and autonomy.

3. Citing the argument of scholar William C. Harris, Elizabeth Fenton notes that "the nation's motto-'E pluribus unum' or 'From many, one'-suggests ... the 'logical contradiction on which the nation was founded ... the simultaneous execution of the principles of unity and equality" (3). 4. See Amy Kaplan's cogent argument that the "gendered spheres were ... complexly intermeshed" in the processes of American imperialism (25).

5. In The Servant Girl Question (1881), Spofford examines the changing nature of domestic service as Irish Roman Catholic servants "invaded" and colonized Protestant hearths and homes (29). Spofford viewed immigration as part and parcel of imperial expansion. In The Servant Girl Question, Spofford ties the influx of Irish immigrants to the annexation of Ireland when she writes that Ireland would become a new statemaking light of this fact but reflecting popular fears. Spofford here too weakens and dissolves the boundary between domestic and foreign territory, American and Other, by representing the reciprocal influence between mistress and domestic (53).

6. In "Women, Anti-Catholicism, and Narrative in Nineteenth-Century America," Susan Griffin explains that the Charlestown riot was considered a national scandal that drew a great deal of attention (162). Jenny Franchot points out that the attack on the convent was "arguably the most important political event in Massachusetts prior to the agitation surrounding the passage of the 1850 fugitive Slave Law" (136).

7. See Franchot 143.

8. Joel Pfister makes this point about the built environment of Nathaniel Hawthorne's "Mainstreet" (37).

9. Susan Griffin makes this point in her examination of convent tales ("Women" 160).

10. For example, in an anti-Catholic sermon repeatedly delivered in the 1840s, Henry Augustus Boardman describes "Popery" and the confessional as "chaining" people and enslaving their consciences (17).

11. Nancy F. Sweet points out that most scholars who examine anti-Catholic literature in the U.S. link this discourse to nativism, but that it was actually a "transnational preoccupation" (99). She explains that it "literally traveled across the Atlantic during the second quarter of the nineteenth century" and can be traced back to "efforts to grant civil rights to Catholic Britons ... in earnest in the $1820 \mathrm{~s} "(99,100)$.

12. Susan Griffin explains that "the spread of Roman Catholicism ... was viewed by Protestants as 'an outright invasion"' (Anti 16).

13. Marie Anne Pagliarini explains that the role of the priest as confessor to women was particularly troubling to Protestants, who linked this role to the priest's sexual exploitation of women (105).

14. The mob recognizes that "woman's true sphere," as described by Amy Kaplan "was in fact a mobile and mobilizing outpost that transformed conquered foreign lands into the domestic 
sphere of the family and nation" (Kaplan 25). Spofford imagines her role as domesticating the minds of her readers.

15. Joel Pfister uses these terms to describe Nathaniel Hawthorne (35).

\section{ABSTRACTS}

In "Charlestown," an historical sketch from her 1871 collection New-England Legends, Harriet Prescott Spofford examines the contest between Protestantism and Roman Catholicism that shaped Americans' understanding of democracy as well as Spofford's understanding of her role as an author in an increasingly heterogeneous nation. The sketch focuses on the 1834 burning of the Ursuline Convent and School of Mount Benedict in Charlestown, Massachusetts, by a Protestant mob, an assault that affords Spofford the opportunity to examine the nation's ability to accommodate difference of all kinds. Spofford adopts a Protestant aesthetic in order to free readers from entrenched bigotry and unify an increasingly diverse nation. She develops a participatory model of creating consensus in an expanding nation that replicates the dynamic of democracy in the public sphere. Spofford's understanding of the role she plays in the process of imperialism as a woman writer, as well as her sincere efforts to combat bigotry in herself and in her world, require us to reassess her place within the ranks of nineteenth-century American women writers.

\section{INDEX}

Keywords: Harriet Prescott Spofford, historical sketch, Protestantism, Roman Catholicism, Ursuline Convent and School of Mount Benedict, anti-Catholicism, convent tales, bigotry, pluralism, immigration, Charlestown, Massachusetts, Bunker Hill, imperialism, democracy, nativism

\section{AUTHOR}

\section{PAULA KOT}

Paula Kot is an Associate Professor in the Department of English at Niagara University. She teaches nineteenth-century American literature, including special topics courses on nineteenthcentury American women writers. She has published on writers such as Edgar Allan Poe, Lydia Maria Child, Lydia Huntley Sigourney, Harriet Prescott Spofford, Elizabeth Stoddard, and Willa Cather. 